\title{
Enhanced Production of Astaxanthin by Metabolic Engineered Isoprenoid Pathway in Escherichia coli
}

\author{
Jae Hyung Lee, Yong Bae Seo ${ }^{1}$ and Young Tae Kim* \\ Basic Science Research Institute, Pukyong National University, Busan 608-737, Korea \\ ${ }^{1}$ Department of Microbiology, Pukyong National University, Busan 608-737, Korea
}

Received October 15, 2008 / Accepted December 16, 2008

\begin{abstract}
The goal of this study is to increase production of astaxanthin in recombinant Escherichia coli by engineered isoprenoid pathway. We have previously reported structural and functional analysis of the astaxanthin biosynthesis genes from a marine bacterium, Paracoccus haeundaensis. The carotenoid biosynthesis gene cluster involved in astaxanthin production contained six carotenogenic genes (crtW, crtZ, crtY, crtI, crtB, and crtE genes) and recombinant E. coli harboring six carotenogenic genes from $P$. haeundaensis produced $400 \mu \mathrm{g} / \mathrm{g}$ dry cell weight (DCW) of astaxanthin. In order to increase production of astaxanthin in recombinant $E$. coli, we have cloned 4-hydroxy-3-methylbut-2-enyl diphosphate reductase $(l y t B)$, farnesyl diphosphate (FPP) synthase (ispA), and isopentenyl (IPP) diphossphate isomerase (idi) in the isoprenoid pathway from E. coli and coexpressed these genes in recombinant E. coli harboring the astaxanthin biosynthesis genes. This engineered E. coli strain containing both isoprenoid pathway gene and astaxanthin biosynthesis gene cluster produced 1,200 $\mu \mathrm{g} / \mathrm{g}$ DCW of astaxanthin, resulting 3-fold increased production of astaxanthin.
\end{abstract}

Key words : Astaxanthin, carotenoid, isoprenoid, Paracoccus haeundaensis

Carotenoids are natural lipid-soluble pigments produced primarily from bacteria, algae, and plants. Carotenoids have recently attracted as their beneficial effects on human health such as functions of antioxidants [23,24], an involvement in cancer prevention $[3,8,13]$ and enhancers of immune responses [2,5,10].

Astaxanthin is a carotenoid widely distributed in nature including marine animal tissues such as the red seabream, salmon, and lobster [6,11]. Organisms that produce astaxanthin include the basidiomycetous yeast Phaffia rhodozyma [21], the green alga Haematococcus pluvialis [4], the Gram negative bacteria Agrobacterium aurantiacum [34], Paracoccus marcusii [9], Paracoccus carotinifaciens [30], Paracoccus sp. MBIC1143 [22], and Paracoccus haeundaensis [14]. Even though synthetically produced astaxanthin has some drawbacks to apply commercial application, it is used for both direct and indirect food additives and coloring because naturally purified astaxanthin is very limited. In cosmetology and pharmacology, it is most demanding pigments for use as a dermal photoprotector. Astaxanthin is a pigment of high economic value and various study were carried out to in-

\section{*Corresponding author}

Tel : +82-51-629-5616, Fax : +82-51-629-5619

E-mail : ytkim@pknu.ac.kr creased the production of astaxanthin with the application of metabolic pathway engineering $[1,18,25,28,31]$.

In a previous study, we isolated and characterized a marine bacterium, Paracoccus haeundaensis, which produces astaxanthin [14]. In addition, we reported the structural and functional analysis of genes encoding the astaxanthin biosynthetic enzymes; GGPP synthase (CrtE), phytoene synthase $(\mathrm{CrtB})$, phytoene desaturase $(\mathrm{CrtI})$, lycopene cyclase (CrtY), ß-carotene hydroxylase ( $\mathrm{CrtZ})$, and B-carotene ketolase (CrtW) [15]. The individual gene of the carotenoid biosynthesis gene cluster was functionally expressed in E. coli and each gene product was purified to homogeneity. Their molecular characteristics, including enzymatic activities, were reported [16]. Furthermore, we have reported the pathways and the functions of the astaxanthin biosynthesis genes through chromatographic and spectroscopic analyses of the pigments accumulated in E. coli carrying plasmids constructed by various combinations of the carotenoid biosynthesis genes from the P. haeundaensis [17]. The astaxanthin biosynthesis pathway is summarized in Fig. 1.

Enhanced production of astaxanthin in engineered microbial hosts requires optimization of the available precursors pool of isopentenyl diphosphate (IPP) and dimethylallyl diphosphate (DMAPP), and balancing the expression 


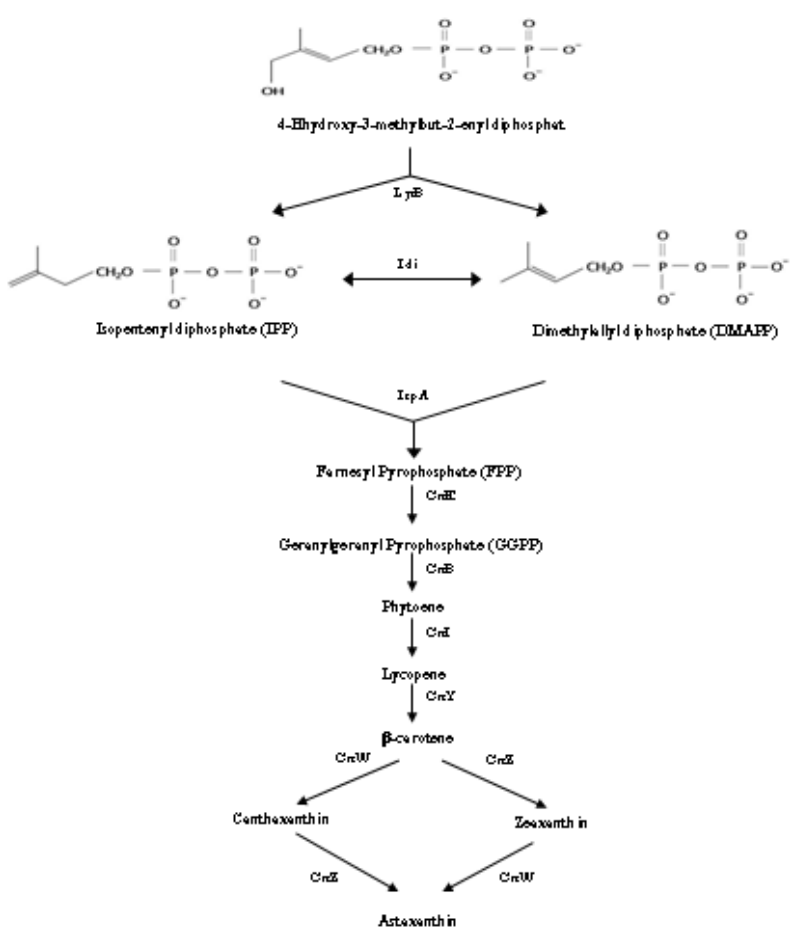

Fig. 1. Scheme of the biosynthesis pathways from 4-Hhydroxy3-methylbut-2-enyl diphosphate to astaxanthin.

of carotenogenic genes for the efficient transformation of the precursors to the desired carotenoid compounds [33]. There are two isoprenoid pathways for the synthesis of IPP; the mevalonate pathway and the 2-C-methyl-D-erythritol 4-phosphate (MEP) pathway [26]. Many enzymes in the isoprenoid pathways have been identified, cloned, and structurally elucidated $[19,27,29,32]$. Even though the E. coli used for the most common hosts in metabolic engineering of the carotenoids production, it has limited supply of the common precursors such as IPP, DMAPP and FPP, because the need for such compounds for growth is relatively small [33]. Therefore, It is essential to develop the E. coli strains producing efficient and increased supply of the common precursors.

The 4-Hydroxy-3-methylbut-2-enyl diphosphate reductase (encoded by $l y t B$ ) catalyses the conversion of 4 Hydroxy-3-methylbut-2-enyl diphosphate into IPP and DMAPP [20]. Once IPP is formed, it is isomerized to DMAPP through IPP isomerase (coded by idi), which, upon successive addition of IPP, leads to FPP through FPP synthase (coded by ispA) as described in Fig. 1 [7].

In the present study, in order to increase the production of the common precursors; IPP, DMAPP and FPP, we have reconstructed the isoprenoid pathway between 1-hydroy-2methyl-2-(E)-butenyl 4-diphosphate and FPP in E. coli and overexpressed the isoprenoid pathway genes $(l y t B, i d i$, and ispA genes) from E. coli. Theses genes were introduced into the $E$. coli strain harboring the astaxanthin biosynthesis gene cluster (crtE, crtB, crtI, crtY, crtZ, and crtW genes) of the $P$. haeundaensis. The coexpression of both isoprenoid pathway and astaxanthin biosynthesis genes resulted 3-folds enhanced production of astaxanthin.

E. coli strain XL1-blue $\left[\mathrm{F}^{\prime}::\right.$ proA $^{+} B^{+}$lacI $I^{q}$ (lacZ) M15/Tn10 $\left(\right.$ Tet $\left.{ }^{r}\right) / r e c A 1$ endA1 gyrA96 $\left(\mathrm{Nal}^{r}\right)$ thi hsdR17 $\left(r_{\mathrm{K}}{ }^{-} \mathrm{m}_{\mathrm{K}}{ }^{+}\right)$supE44 relA1 lac] was used for gene cloning experiments. BL21(DE3) Codon Plus RIL (Staratagen, U.S.A.) was used for the production of astaxanthin. E. coli strain BL21(DE3) Codon Plus RIL cells harboring plasmid were cultured at $37^{\circ} \mathrm{C}$ in LB medium containing tetracycline $(100 \mu \mathrm{g} / \mathrm{ml})$ and kanamycine (50 $\mu \mathrm{g} / \mathrm{ml})$.

In order to construct the expression plasmid for the $l y t B$ gene (GenBank Access No. NC_002655) from E. coli, PCR was carried out using a pair of oligonucleotides with lytB-F and lytB-R primers (Table 1) and E. coli genomic DNA as a template, and the PCR product was ligated into pGEM-T-easy vector (Promega, USA). The resulting plasmid, pGEM-T-easy-lytB, was partial digested with both NdeI and $\mathrm{XbaI}$ enzymes. Then, the excised fragment was ligated

Table 1. Oligonucleotides used in this study

\begin{tabular}{|c|c|c|}
\hline Name & Nucleotide sequence & Remarks \\
\hline lytB-F & 5'-CATATGCAGATCCTGTTGGCCAAC-3' & Primer for $l y t B$, forward (Nde I site) \\
\hline lytB-R & 5'-TCTAGATTAATCGACTTCACGAATA-3' & Primer for lytB, reverse (Xba I site) \\
\hline lytB-R2 & 5'-GAATTCTCTAGATTAATCGACTTCAC-3' & Primer for $l y t B$, reverse (EcoR I site) \\
\hline idi-F & 5'-CATATGCAAACGGAACACGTCATTTTATTG-3' & Primer for idi, forward (Nde I site) \\
\hline idi-R & 5'-TCTAGATTATTTAAGCTGGGTAAATGCAG-3' & Primer for $i d i$, reverse (Xba I site) \\
\hline idi-R2 & 5'-GAATTCTCTAGATTATTTAAGCTGGGTAAAT-3' & Primer for $i d i$, reverse (EcoR I site) \\
\hline ispA-F & 5'-CATATGGACTTTCCGCAGCAACTCGAAG-3' & Primer for ispA, forward (Nde I site) \\
\hline ispA-R & 5'-TCTAGATTATTTATTACGCTGGATGATGTAG-3' & Primer for $i s p A$, reverse (Xba I site) \\
\hline ispA-R2 & 5'-GAATTCTCTAGATTATTTATTACGCTGGATG-3' & Primer for ispA, reverse (EcoR I site) \\
\hline HCF-F & 5'-GAATTCGATCTCTCCTTCACAGATTCCC-3' & Primer for HCE promoter, forward (EcoR I site) \\
\hline
\end{tabular}


into pHCE IIB plasmid (NdeI) (Takara, Japan) with a constitutive HCE promoter of Geobacillus toebii and resulted in as pHCE IIB-lytB plasmid (Fig. 2). In the next step, PCR was performed using a pair of oligonucleotides with HCE-F and lytB-R2 primers (Table 1) and pHCE IIB-lytB (Fig. 2) as a template, and ligated into pGEM-T-easy vector. The resulting plasmid, pGEM-T-easy-HCE-lytB, was digested with EcoRI enzyme and ligated into pACYC184 plasmid (Novagen, USA) previously digested with EcoRI enzyme and treated with calf intestinal alkaline phosphatase (CIAP) for preventing self-ligation. The resulting plasmid, pACYC184lytB (Fig. 2), was transformed into E. coli BL21(DE3) Codon Plus RIL.

To construct the expression plasmid for the idi gene (GenBank Access No. CP000948) from E. coli, it was carried out that PCR using a pair of oligonucleotides with idi-F and idi-R primers (Table 1) and E. coli genomic DNA as a template, and the PCR product was ligated into pGEM-T-easy vector. The resulting plasmid, pGEM-T-easy-idi, was digested with both NdeI and XbaI enzymes. Then, the excised fragment was ligated into $\mathrm{pHCE}$ IIB(NdeI) with constitutive HCE promoter and resulted in as pHCE IIB-idi plasmid (Fig. 2). In the next step, PCR was performed using a pair of oligonucleotides with HCE-F and idi-R2 primers (Table 1) and pHCE IB-idi (Fig. 2) as a template, and ligated into pGEMT-easy vector. The resulting plasmid, pGEM-T-easy-HCE-idi, was digested with EcoRI enzyme and ligated into pACYC184 plasmid previously digested with EcoRI enzyme and treated with calf intestinal alkaline phosphatase (CIAP) for preventing self-ligation. The resulting plasmid, pACYC184-idi (Fig. 2), was transformed into E. coli BL21(DE3) Codon Plus RIL. In order to construct the expression plasmid for the isp A gene (GenBank Access No. D00694) from E. coli, it was carried out that PCR using a pair of oligonucleotides with ispA-F and ispA-R primers (Table 1) and E. coli genomic DNA as a template, and the PCR product was ligated into pGEM-T-easy vector. The resulting plasmid, pGEM-T-easyispA, was digested with both NdeI and XbaI enzymes. Then, the excised fragment was ligated into $\mathrm{pHCE}$ IIB(Ndel) with constitutive HCE promoter and resulted in as pHCE IIB-ispA plasmid (Fig. 2). In the next step, PCR was performed using a pair of oligonucleotides with HCE-F and ispA-R2 primers (Table 1) and PHCE IIB-ispA (Fig. 2) as a template, and ligated into pGEM-T-easy vector. The resulting plasmid, pGEM-T-easy-HCE-ispA, was digested with EcoRI enzyme and ligated into pACYC184 plasmid previously digested with EcoRI enzyme and treated with calf intestinal alkaline phosphatase (CIAP) for preventing self-ligation. The resulting plasmid, pACYC184-ispA (Fig. 2), was transformed into E. coli BL21(DE3) codon plus. In a previous study, we constructed $\mathrm{pCR}$-XL-TOPO-Crt-full plasmid carrying the full-length astaxanthin biosynthesis gene cluster [15]. The pCR-XL-TOPO-Crt-full plasmid and pACYC184lytB, pACYC184-idi, and pACYC184-ispA plasmid, respectively were transformed into E. coli BL21(DE3) Codon Plus RIL.

Ten grams of the lyophilized cells of E. coli BL21(DE3) Codon Plus RIL carrying a plasmid were resuspended in $10 \mathrm{ml}$ acetone and incubated over night at $4^{\circ} \mathrm{C}$. Acetone was evaporated and the pellet was dissolved in $10 \mathrm{~mL}$ of $n$-hexane-ethanol $(1: 1, v / v)$. Then, the extract was diluted to $1 / 2$ with distilled water, and two phases were separated with a separatory funnel. Organic phase (n-hexane phase) was washed with 30\% aqueous ethanol until colorless and near
(A)

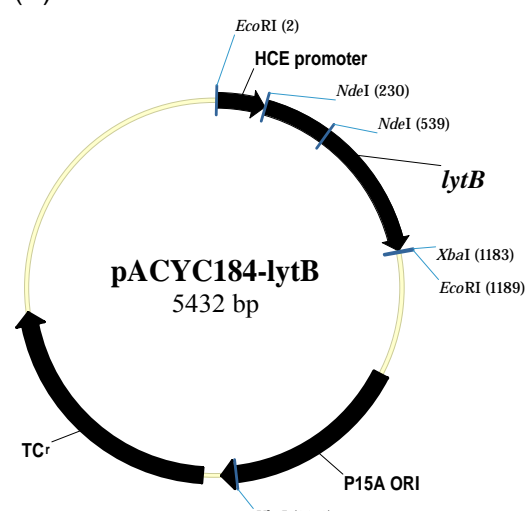

(B)
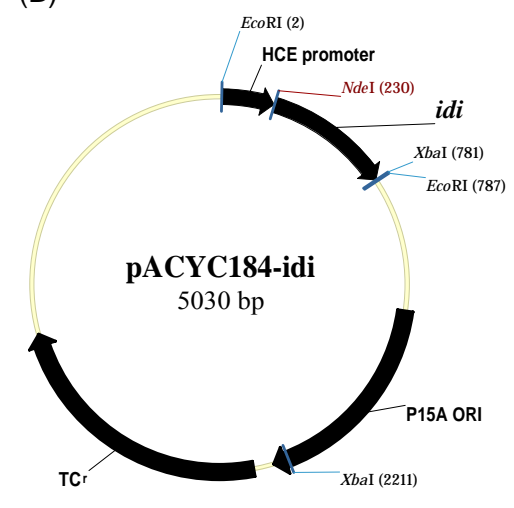

(C)

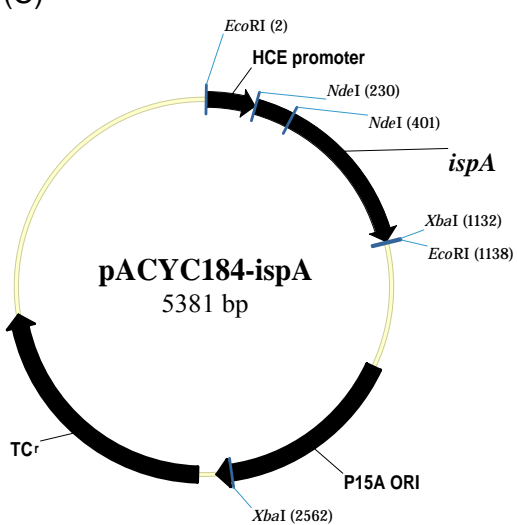

Fig. 2. Structure of plasmid A; pACYC184-lytB, B; pACYC184-idi. and C; pACYC184-ispA, respectively. 
neutral pH. After separation, the organic phase was blown to dryness under a stream of nitrogen, and then, the residue was stored in a refrigerator.

The astaxanthin extract was dissolved in 2-propanol and subjected onto high-performance liquid chromatography (HPLC). Chromatography was performed using an Agilent 1100 HPLC system equipped with a temperature-controlled autosampler and a diode array detector. The column was a YMC carotenoid $\mathrm{C}_{30}$ colum (5 micron, steel, $250 \mathrm{~mm}$ long $\times 4.6 \mathrm{~mm}$ i.d.; Waters Corp., Milford, MA, USA). The guard column was a Pelliguard LC-18 cartridge $(20 \mathrm{~mm}$; SUPELCO, Bellefonte, PA, USA). The mobile phase was a methanol/methyl tert-butyl ether $(\mathrm{A} / \mathrm{B})$ gradient having the following parameters (all percentages expressed as $\mathrm{v} / \mathrm{v}$ ) start, $80 \% \mathrm{~A} / 20 \%$ B; $10 \mathrm{~min}, 65 \% \mathrm{~A} / 35 \% \mathrm{~B} ; 20 \mathrm{~min}, 10 \%$ $\mathrm{A} / 90 \% \mathrm{~B}$. The flow rate was $1.0 \mathrm{ml} / \mathrm{min}$. The injection volume and column temperature were $10 \mathrm{ml}$ and $15^{\circ} \mathrm{C}$, respectively. Astaxanthin was detected by absorbance at 470 nm (for phytoene, at $286 \mathrm{~nm}$ ) and was purchased from Sigma (U.S.A.).

To calculate the amount of the accumulated astaxanthin from the transformed cells, the following equation was used [12].

$$
\text { Total carotenoid }(\mathrm{g})=\frac{\mathrm{ml} \text { of solvent } \times \mathrm{A}_{\lambda \max }}{\mathrm{E} \frac{1 \%}{1 \mathrm{~cm}} \times 100}
$$

The specific absorbance coefficient, $\mathrm{A}_{1 \mathrm{~cm}}^{1 \%}$ (= specific extinction coefficient, $\left.\mathrm{E}_{1 \mathrm{~cm}}^{1 \%}\right)$, where representing the absorbance of $1 \%(\mathrm{w} / \mathrm{v})$ solution $(1 \mathrm{~g} / 100 \mathrm{ml})$ in a $1-\mathrm{cm}$ path cuvette at the appropriate wavelength, was applied for the determination of the concentrations of astaxanthin.

As shown in Figure 1, the $l y t B, i d i$, and isp $A$ genes in the isoprenoid pathway are essential for biosynthesis of IPP, DMAPP and FPP. Theses precursors are crucial compounds for the efficient production of astaxanthin from FPP. However, E. coli cell has limited supply of these common precursors because E. coli cell itself needs only small amount of such compounds for growth. In the present study, the $l y t B, i d i$, and isp A genes from E. coli were cloned and in- troduced into separate E. coli strains for comparisons of the common precursors. The results showed the efficient production of IPP, DMAPP and FPP. In order to increase production of astaxanthin, we have used these strains for co-expression of both the astaxanthin biosynthesis gene cluster (pCR-XL-TOPO-Crt-full containing crtW, crtZ, crtY, crtI, crtB, and $c r t E$ genes) from $P$. haeundaensis and the $l y t B$, idi, and ispA genes in the isoprenoid pathway.

The plate of the cells transformed with pCR-XL-TOPOCrt-full and pACYC184-lytB plasmid was shown in a red color, indicating that the expressed proteins; LytB, CrtE, CrtB, CrtI, CrtY, CrtZ, and CrtW, mediate the formation of a red colored astaxanthin through metabolic intermediates; zeaxanthin, $\beta$-carotene, lycopene, phytoene, GGPP, FPP, IPP, and DMAPP from 4-Hydroxy-3-methylbut-2-enyl diphosphate as summarized in Fig. 1. In order to calculate the amount of the accumulated carotenoids from the transformed cells, the equation (1) was introduced [12]. The amounts of accumulated astaxanthin, zeaxanthin, and $\beta$-carotene were calculated to $480 \mu \mathrm{g} / \mathrm{g}$ DCW (dry cell weight), $210 \mu \mathrm{g} / \mathrm{g}$ DCW, and $90 \mu \mathrm{g} / \mathrm{g}$ DCW, respectively.

The plate of the cells transformed with pCR-XL-TOPOCrt-full and pACYC184-idi plasmid was also shown in a red colored astaxanthin, indicating that the expressed proteins; Idi, CrtE, CrtB, CrtI, CrtY, CrtZ, and CrtW, mediate the formation of a red color astaxanthin via intermediate carotenoids; zeaxanthin, $\beta$-carotene, lycopene, phytoene, GGPP, and FPP from IPP and DMAPP. The amounts of astaxanthin, zeaxanthin, and $\beta$-carotene using the formula (1) were calculated to $1,200 \mu \mathrm{g} / \mathrm{g} \mathrm{DCW}, 410 \mu \mathrm{g} / \mathrm{g} \mathrm{DCW}$, and $250 \mu \mathrm{g} / \mathrm{g}$ DCW, respectively.

The plate of the cells transformed with pCR-XL-TOPOCrt-full and pACYC184-ispA plasmid was shown in a red color, indicating that the expressed proteins, IspA, CrtE, CrtB, CrtI, CrtY, CrtZ, and CrtW, mediate the formation of a red colored astaxanthin via zeaxanthin, $\beta$-carotene, lycopene, phytoene, GGPP, and FPP from IPP and DMAPP. The amounts of astaxanthin, zeaxanthin, and $\beta$-carotene using the formula (1) were calculated to $650 \mu \mathrm{g} / \mathrm{g}$ DCW, $290 \mu \mathrm{g} / \mathrm{g}$

Table 2. The amount of astaxanthin accumulated in E. coli transformants carrying various plasmids

\begin{tabular}{llc}
\hline \multicolumn{1}{c}{ Plasmids } & \multicolumn{1}{c}{ Genes } & Astaxanthin content $(\mu \mathrm{g} / \mathrm{g}$ DCW $)$ \\
\hline pCR-XL-Topo-Crt full & crtEBIYZW & $400( \pm 20)$ \\
pCR-XL-Topo-Crt full and pACYC184-lytB & crtEBIYZW and lytB & $480( \pm 70)$ \\
pCR-XL-Topo-Crt full and pACYC184-idi & crtEBIYZW and idi & $1200( \pm 50)$ \\
pCR-XL-Topo-Crt full and pACYC184-ispA & $c r t E B I Y Z W$ and ispA & $650( \pm 90)$ \\
\hline
\end{tabular}




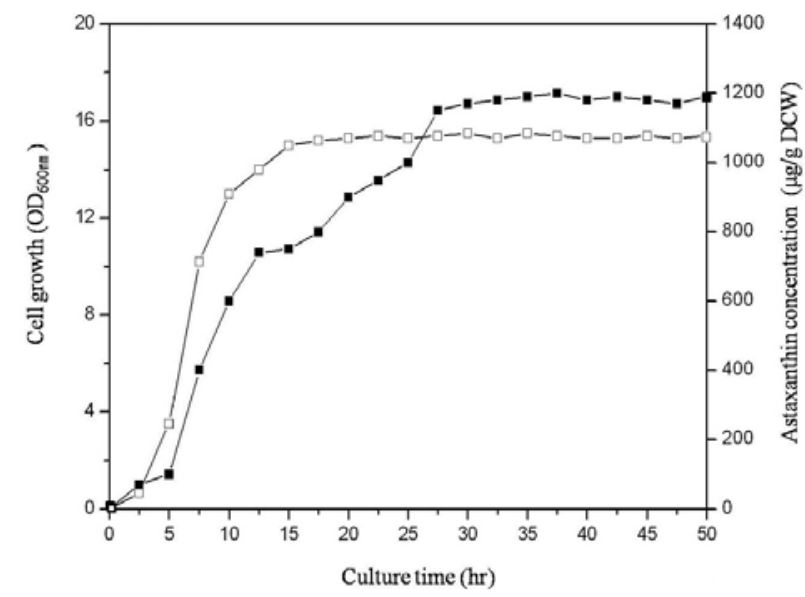

Fig. 3. Time profiles of cell growth and astaxanthin production $(\mu \mathrm{g} / \mathrm{g}$ DCW). BL21(DE3) Codon Plus RIL was used as the host strain with the pCR-XL-TOPO-Crt-full and pACYC184-idi plasmids that lead to astaxanthin production. $(\square)$, cell growth; $(\square)$, astaxanthin in LB medium.

DCW, and $120 \mu \mathrm{g} / \mathrm{g}$ DCW DCW, respectively. The accumulated amount of produced astaxanthin of these strains are summarized in Table 2.

We have previously reported the expression of the astaxanthin biosynthesis gene cluster (pCR-XL-TOPO-Crt-full containing $c r t W, c r t Z, c r t Y, c r t I, c r t B$, and $c r t E$ genes) from P. haeundaensis in E. coli BL21(DE3) Codon Plus RIL [15]. With comparisons of produced astaxanthin contents from those data with this study, the amounts of accumulated astaxanthin by the co-expression system of both the $l y t B, i d i$, and ispA genes in the isoprenoid pathway and the astaxanthin biosynthesis gene cluster (pCR-XL-TOPO-Crt-full containing $c r t W, c r t Z, c r t Y, c r t I, c r t B$, and $c r t E$ genes) have higher values than those of the expression system using only astaxanthin biosynthesis genes. This engineered E. coli strain containing both isoprenoid pathway genes and astaxanthin biosynthesis gene cluster (both pCR-XL-TOPO-Crt-full and pACYC184-idi plasmid) produced $1200 \mu \mathrm{g} / \mathrm{g}$ DCW of astaxanthin, resulting 3-folds increased production of astaxanthin compared to the E. coli transformant harboring only pCR-XL-TOPO-Crt-full plasmid.

Growth patterns and astaxanthin production from recombinant E. coli cells harboring pCR-XL-TOPO-Crt-full and pACYC184-idi plasmid were shown in Fig. 3. The recombinant $E$. coli strains were grown in batch culture for $50 \mathrm{hr}$ with shaking in LB medium containing tetracycline $(100 \mu \mathrm{g}$ $/ \mathrm{ml})$ and kanamycine $(50 \mu \mathrm{g} / \mathrm{ml})$ at $37^{\circ} \mathrm{C}$. The production of astaxanthin reached a plateau after $30 \mathrm{hr}$ incubation. In the present study, we have achieved the enhanced production of astaxanthin by the co-expression system using the combinational constructs of the carotenoid biosynthesis genes from $P$. haeundaensis and isoprenoid biosynthesis genes from E. coli. Consequently, the results of this study can be used to enhance the production of astaxanthin through the manipulation of carotenoid biosynthesis genes in P. haeundaensis and isoprenoid biosynthesis genes from E. coli, and an important application since astaxanthin is a pigment of high economic value. These data will provide a wider base of knowledge on the gene expression of the astaxanthin biosynthesis gene cluster at the molecular level as well as further the biotechnological applications of carotenoids. Moreover, the possibility to control separately the expression levels of the $l y t B, i d i$, and isp $A$ genes in $E$. coli will provide us with wider applications of the E. coli co-expression system.

\section{Acknowledgment}

This work was supported by Korea Research Foundation Grant (KRF-2004-041-F00059).

\section{References}

1. Alper, H., Y. S. Jin, J. F. Moxley and G. Stephanopoulos. 2005. Identifying gene targets for the metabolic engineering of lycopene biosynthesis in Escherichia coli. Metab. Eng. 7, 155-164.

2. Amar, E. C., V. Kiron, S. Satoh and T. Watanabe. 2004. Enhancement of innate immunity in rainbow trout (Oncorhynchus mykiss Walbaum) associated with dietary intake of carotenoids from natural products. Fish Shellfish Immunol. 16, 527-537.

3. Bertram, J. S. and A. L. Vine. 2005. Cancer prevention by retinoids and carotenoids: independent action on a common target. Biochim. Biophys. Acta. 1740, 170-178.

4. Bubrick, P. 1991. Production of astaxanthin from Haematococcus. Bioresour. Technol. 38, 237-239.

5. Chew, B. P. and J. S. Park. 2004. Carotenoid action on the immune esponse. J. Nutr. 134, 257S-261S.

6. Fujita, T., M. Satake, T. Watanabe, C. Kitajima, W. Miki, K. Yamaguchi and S. Konosu. 1983. Pigmentation of cultured red sea bream with astaxanthin diester purified from krill oil. Nippon Suisan Gakkaishi. 49, 1855-1865.

7. Fujisaki, S., H. Hara, Y. Nishimura, K. Horiuchi and T. Nishino. 1990. Cloning and nucleotide sequence of the ispA gene responsible for farnesyl diphosphate synthase activity in Escherichia coli. J. Biochem. 108, 995-1000.

8. Giovannucci, E., A. Ascherio, E. B. Rimm, M. J. Stampfer, 
G. A. Colditz and W. C. Willett. 1995. Intake of carotenoids and retinol in relation to risk of prostate cancer. J. Natl. Cancer. Inst. 87, 1767-1776.

9. Harker, M., J. Hirschberg and A. Oren. 1998. Paracoccus marcusii sp. nov., an orange Gram negative coccus. Int. J. Syst. Bacteriol. 48, 543-548.

10. Hix, L. M., S. F. Lockwood and J. S. Bertram. 2004. Bioactive carotenoids: potent antioxidants and regulators of gene expression. RedoxRep. 9, 181-191.

11. Johnson, E. A. and G. H. An. 1991. Astaxanthin from microbial sources. Crit. Rev. Biotechnol. 11, 297-326.

12. Johnson, E. A., D. B. Schuman and G. H. An. 1989. Isolation of mutants with increase astaxanthin content. Appl. Environ. Microbiol. 55, 116-124.

13. Kurihara, H., H. Koda, S. Asami, Y. Kiso and T. Tanaka. 2002. Contribution of the antioxidative property of astaxanthin to its protective effect on the promotion of cancer metastasis in mice treated with restraint stress. Life Sci. 70, 2509-2520.

14. Lee, J. H., Y. S. Kim, T. J. Choi, W. J. Lee and Y. T. Kim. 2004. Paracoccus haeundaensis sp. nov., a Gram-negative, halophilic, astaxanthin-producing bacterium. Int. J. Syst. Evol. Microbiol. 54, 1699-1702.

15. Lee, J. H. and Y. T. Kim. 2006. Cloning and characterization of the astaxanthin biosynthesis gene cluster from the marine bacterium Paracoccus haeundaensis. Gene 370, 86-95.

16. Lee, J. H. and Y. T. Kim. 2006. Functional expression of the astaxanthin biosynthesis genes from a marine bacterium, Paracoccus haeundaensis. Biotechnol. Lett. 28, 1167-1173.

17. Lee, J. H., Y. B. Seo, S. Y. Jeong, S. W. Nam and Y. T. Kim. 2007. Functional analysis of combinations in astaxanthin biosynthesis genes from Paracoccus haeundaensis. Biotecnol. Bioprocess Eng. 12, 312-317.

18. Lee, P. C., B. N. Mijts and C. Schmidt-Dannert. 2004. Investigation of factors influencing production of the monocyclic carotenoid torulene in metabolically engineered Escherichia coli. Appl. Microbiol. Biotechnol. 65, 538-546.

19. Lesburg, C. A., G, Zhai, D. E. Cane and D. W. Christianson. 1997. Crystal structure of pentalenene synthase: Mechanistic insights on terpenoid cyclization reactions in biology. Science 277, 1820-1824.

20. Maateer, S., A. Coulson, N. Mclennan and M. Masters. 2001. The lytB gene of Escherichia coli is essential and specifies a product needed for isoprenoid bioysynthesis. J. Bacteriol. 183, 7403-7407.

21. Miller, M., W. M. Yoneyama and M. Soneda. 1976. Phaffia, a new yeast genus in the Deuteromycotina (Blastomycetes).
Int. J. Syst. Bacteriol. 26, 286-291.

22. Misawa, N., Y. Satomi, K. Kondo, A. Yokoyama, S. Kajiwara, T. Saito, T. Ohtani and W. Miki. 1995. Structure and functional analysis of a marine bacterial carotenoid biosynthesis gene cluster and astaxanthin biosynthetic pathway proposed at the gene level. J. Bacteriol. 177, 6575-6584.

23. Murtaugh, M. A., K. N. Ma, J. Benson, K. Curtin, B. Caan and M. L. Slattery. 2004. Antioxidants, carotenoids and risk of rectal cancer. Am. J. Epidemiol. 159, 32-41.

24. Neuman, I., H. Nahum and A. Ben-Amotz. 2000. Reduction of exercise-induced asthma oxidative stress by lycopene, a natural antioxidant. Allergy 55, 1184-1189.

25. Ralley, L., E. M. Enfissi, N. Misawa, W. Schuch, P. M. Bramley and P. D. Fraser. 2004. Metabolic engineering of ketocarotenoid formation in higher plants. Plant J. 39, 477-486.

26. Rohmer, M. 1999. The discovery of a mevalonate-independent pathway for isoprenoid biosynthesis in bacteria, algae and higher plants. Nat. Prod. Rep. 16, 565-574.

27. Starks, C. M., K. Back, J. Chappell and J. P. Noel. 1997. Structural basis for cyclic terpene biosynthesis by tobacco 5-epi-aristolochene synthase. Science 277, 1815-1820.

28. Tao, L., L. W. Wagner, P. E. Rouvière and Q. Cheng. 2006. Metabolic engineering for synthesis of aryl carotenoids in Rhodococcus. Appl. Microbiol. Biotechnol. 70, 222-228.

29. Tarshis, L. C., M. Yan, C. D. Poulter and J. C. Sacchettini. 1994. Crystal structure of recombinant farnesyl diphosphate synthase at 2.6- $\AA$ resolution. Biochemistry 33, 10871-10877.

30. Tsubokura, A., H. Yoneda and H. Mizuta, 1999. Paracoccus carotinifaciens sp. nov., a new aerobic Gram negative astaxanthin producing bacterium. Int. J. Syst. Bacteriol. 49, 277-282.

31. Wang, C. W., M. K. Oh and J. C. Liao. 1999. Engineered isoprenoid pathway enhances astaxanthin production in Escherichia coli. Biotechnol. Bioeng. 62, 235-241.

32. Wendt, K. U., K. Poralla and G. E. Schulz. 1997. Structure and function of a squalene cyclase. Science 277, 1811-1815.

33. Yoon, S. W., Y. M. Lee, J. E. Kim, S. H. Lee, J. H. Lee, J. Y. Kim, K. H. Jung, Y. C. Shin, J. D. Keasling and S. W. Kim. 2006. Enhanced lycopene production in Escherichia coli engineered to synthesize isopentenyl diphosphate and dimethylallyl diphosphate from mevalonate. Biotechnol. Bioeng. 94, 1025-1032.

34. Yokoyama, A., H. Izumida and W. Miki. 1994. Production of astaxanthin and 4-ketozeaxanthin by the marine bacterium, Agrobacterium aurantiacum. Biosci. Biotechnol. Biochem. 58, 1842-1844. 
초록 : 대장균에서 이소프레노이드 생합성 경로의 대사공학적 개량에 의한 아스타잔틴의 생산성 향상 이재형 · 서용배 ${ }^{1} \cdot$ 김영태 ${ }^{1} \star$

(부경대학교 기초과학연구소, ${ }^{1}$ 자연과학대학 미생물학과)

이 연구의 목적은 생물공학적으로 이소프레노이드 생합성 유전자를 클로닝하여 이들을 형질전환시킨 대장균을 제조하여 이들을 숙주로 사용하여 아스타잔틴의 생산을 증가시키는 것이다. 본 연구진은 선행연구에서 Paracoccus haeundaensis로부터 아스타잔틴 생산에 관여하는 6개의 아스타잔틴 생합성 유전자군을 보고하였고, 이들 유전자들 을 발현 벡타(pCR-XL-TOPO-Crt)에 재조합한 후 이 벡터를 대장균에 형질 전환시켜서 건조중량으로 $400 \mu \mathrm{g} / \mathrm{g}$ 의 아스타잔틴을 생산하였다. 아스타잔틴의 생산성을 증가시키기 위해서 대장균으로부터 이소프레노이드 생합성 경 로에 관여하는 4-hydroxy-3-methylbut-2-enyl diphosphate reductase (lytB), farnesyl diphosphate (FPP) synthase (ispA), isopentenyl (IPP) diphossphate isomerase (idi) 유전자들을 클로닝하였고, 이들 유전자를 (pCR-XL-TOPOCrt-full)와 같이 대장균에 각각 공발현시켰다. idi 유전자와 아스타잔틴 생산에 관여하는 아스타잔틴 생합성 유전자 군이 함께 형질 전환된 BL21(DE3) Codon Plus RIL 대장균를 배양하였을때, 건조중량으로 $1,200 \mu \mathrm{g} / \mathrm{g}$ 의 아스타잔틴 을 생산하였다. 따라서 본 연구 결과, 이소프레노이드 생합성 유전자와 아스타잔틴 생합성 유전자군을 공발현 시킬 때 아스타잔틴의 생산이 3 배 증가하였다. 